\title{
Adolescents previously involved in Satanism experiencing mental health problems
}

H Heathcote

M. Cur. (Psychiatric Nursing) RAU

\&

A Gmeiner

D. Cur (Psychiatric Nursing) RAU

\&

M. Poggenpoel

Ph. D. (Psychiatric Nursing) RAU

The overall objective is the exploration and description of the phenomenon of the adolescent involved in Satanism and who experiences obstacles in his / her quest for mental wholeness. Guidelines for nurses regarding the management of these adolescents will subsequently follow.

\section{OPSOMMING}

Navorsing oor die verskynsel van adolessente wat betrokke was by Satanisme en struikelblokke ervaar in hulle strewe na geestesgesondheid is nog nie voorheen onderneem nie. Adolessente wat betrokke was by Satansime presenteer gedragsprobleme soos agressiewe uitbarstings depressie, "psigose" of selfmoordpogings wat selfs op selfmoord kan uitloop. In die verskynsel-analise is fenomenologiese onderhoude met die respondente en hulle ouers gevoer. Die respondente is gevra om ' $n$ naïewe skets oor hulle lewe te skryf. Nadat die datakontrole uitgevoer is, is riglyne opgestel vir verpleegkundiges vir die hantering van die adolessent wat betrokke was by Satanisme en struikelblokke ervaar in hulle strewe na geestesgesonehid. In die data-kontrole is gesprekke met kundiges gevoer, literatuur (boeke, tydskrifte en koerantuitknipsels) is nageslaan om die geldigheid van die navorsing te bewys. Die belangrikste riglyne aan die verpleegkundiges is dat die hulpgewers wedergebore Chirstene moet wees; hulle moet geen vrees wys nie; hulle moet nie simpatie wys aan die adolessente nie; hulle moet oor kennis van Satanisme beskik; die adolessent moet onvoorwaardelik aanvaar word; die hulpgewers moet in 'n span saamwerk en die adolessent moet geleer word om emosies te hanteer.

\section{INTRODUCTION}

Involvement in Satanism creates a problem in every area of mental health. Drugand alcohol-abuse, animal cruelty and killing of animals during rituals, violation of tombstones and corpses, sexual malpractice, murder and suicide, child molesting and various other sociopathologies appear.

The Citizen of 23 September 1992 reports on a sixteen-year old girl and her friend, both self-acknowledged Satanists, who killed her mother. She claimed that Satan forced her to execute
ABSTRACT

No research has previously been done regarding the phenomenon of adolescents who have previously been involved in Satanism and who experience obstacles in their strive for mental health. Adolescents previously involved in Satanism present behavioral problems like aggressive outbursts, depression, "psychosis" or suicide attempts, that could lead to suicide. In the phenomenonanalysis semi-structured, phenomenological interviews were performed with the respondents and their parents. The respondents were requested to write a naive sketch about their life. After completion of the data-control, guidelines for nursing staff were set. The guidelines are set for the management of adolescents who have previously been involved in Satanism and who experience obstacles in their strive for mental health. Interviews with experts in Satanism were conducted, literature in the form of books, magazines and newspaper-clippings were used to verify the research findings. The most important guidelines are that the caregivers have to be reborn Christians; they are not allowed to show any fear or sympathy; they must have sufficient knowledge about Satanism; the adolescents have to be unconditionally accepted; the caregivers have to work in a team and the adolescents have to be taught to deal with their emotions.

the murder, that she wanted to stop, but could not do so.

The magazine "Die Huisgenoot" reported on 10 August 1995 on an interview conducted with a defenseless young woman who was cruelly attacked, raped and left to die by two Satanists.

The psychiatric nursing protessionals and other nursing professionals are often confronted with adolescents who experience problems in their quest for mental health.

Adolescents sometimes don't react to 
medication or therapy. On further investigation, it is often found that these adolescents were previously involved in Satanism.

Satanism has never really been acknowledged by the medical profession as a contributing factor to mental health problems.

\section{PROBLEM} STATEMENT

No previous scientific studies have been conducted to explore and describe the phenomenon of adolescents previously involved in Satanism, and who experience obstacles in their strive for mental health.

In the Vaal Triangle-area there are increasing Satanic activities and an awareness thereof.

The effect is observable in the references received by hospitals, occult-branches and psychiatric community services.

Nursing practitioners don't have guidelines to mobilise resources to assist these adolescents in their quest for mental health.

Based on the preceding, the purpose of the study is as follows:

The overall objective is the exploration and description of the phenomenon of the adolescent involved in Satanism and who experiences obstacles in his / her quest for mental wholeness. Guidelines for nurses regarding the management of these adolescents will subsequently follow.

\section{RESEARCH DESIGN- AND METHOD}

The research design was qualitative, exploratory, descriptive and contextual (Mouton and Marais, 1992:45. 52-53, 59 \& Denzin \& Lincoln, 1994:210).

A phenomen-analysis design was followed where two respondents were purposefully chosen on the basis of their experience of, and involvement in Satanism.

The researcher tried to include two adolescents, but because of secrecy and lacking ego-strength in adolescents involved in Satanism, the second respondent was chosen on the basis of her involvement with and experience of Satanism. She is twenty-seven years of age, and has been involved in Satanism from the age of six weeks to twenty-one. The research was conducted in two phases. Phase one consisted of phenomenological interviews conducted with the respondents, which was taped and transcribed verbatim. Interviews were conducted with a parent of each respondent, and the same procedure was followed. Each respondent was requested to write a naive sketch regarding his life as part of data-collection.

Only one respondent did this, the other returned to Satanism before she could do so. The researcher kept reflexive field-notes as part of data-collection (Woods \& Catanzaro, 1988:283).

Data processing was done according to a descriptive analysis according to Tesch (in Creswell, 1994:155). An independent coder was requested to do independent data-analysis according to the agreed protocol, whereafter the researcher and the independent coder held consensus discussions. Discussions with experts on Satanism and a literature-control served as data-control.

The study was conducted from a JudeoChristian perspective according to the Oral Roberts University (1990:136-142), from which the Nursing for the Whole Person Theory originated. The Botesresearch model (1989:1-283) was followed focusing on the functional reasoning approach. This study will therefore also describe guidelines for operationalisation in the nursing practice. In phase two guidelines were described derived from the results of phase one for nursing professionals supporting this group of adolescents in the promotion, maintenance and restoration of their mental health as integral part of health.

\section{TRUSTWORTHINESS}

Lincoln \& Guba's (1985:218-331) four strategies for trustworthiness were followed. The researcher had extended exposure to the research field over a period of at least eight months. She kept reflexive field-notes which formed part of data-collection.

Triangulation of data-collection and datacontrol was executed. A dense description of data by the researcher provides the required information to other researchers, should they want to prove transferability. Confirmation was ensured by means of an audit-trail. The

\section{Table 1 : Data-sources and data-collection methods}

\section{Data-sources Data-collection methods}

Adolescents who were involved in Satanism and who experienced obstacles in their strive for mental health.

Family of adolescent

Important persons to the adolescent.
Phenomenological interviews Naive sketches written by the adolescent.

Phenomenological interviews.

researcher placed herself in "brackets" and entered the field from a "don't know" position.

\section{PILOT STUDY AND}

One central question was directed to the respondents. A pilot study was executed to determine if the central question was derrectly. mulated correctly.

The researcher stated the following criably

- the respondents had to live in the Vaal te for at least two years

- must understand, read and write Afrikaans or English;

must have been actively involved in

pletely;

- must experience obstacles in their

Refer to table 1 for data-sources and data-collection methods.

\section{Ethical guldellnes followed}

Informed, written consent was obtained search. The research results were made to the participating adolescould be kept with explicit permission, were destroyed after completion of the reflective field-notes. 
research study (Denzin \& Lincoln, 1994:212).

\section{DATA-ANALYSIS}

Data-analysis was conducted according to Tescsh's (in Creswell, 1994:155) eight steps of data-analysis. The researcher and the independent coder separately did the data-analysis and then conducted consensus discussions.

After data-analysis conclusions and inferences were made.

DATA-CONTROL

Data-control was conducted to enhance the validity and reliability of the study. Refer to table 2.

In the second phase the themes of the first phase were taken, the information obtained from data-control was considered and guidelines were formed for nursing specialists assisting this group of adolescents.

Table 2 : Data control
' $n$ visioen en belewenisse van ' $n$ geestelike dimensie.")

Another adolescent tells of her confusion: "... what I thought is right is now wrong, what I thought is wrong is now right and all these things ... is a lot of confusion, when you're in and when you're out." ("... wat ek gemeen het is reg is nou verkeerd, wat ek gemeen het is verkeerd is nou reg en al hierdie dinge ... dit is baie verwarrend, wanneer jy in is en wanneer jy uit is.")

Superintendent Rabalt referred to the various realities in the control-discussions: "... hy moet sy vrees sien as realiteit - hy moet daarteen opstaan."

("... he must see his fear as reality - he must stand up against it.")

\section{Brutality / pain / trauma / gruesomeness}

The brutality and gruesomeness extend
One adolescent states: "Then there will be rituals that include human sacrifice, and the same measure of torment and torturing they inflict upon animals, they'll do to children." ("En dan is daar rituele wat menslike offers insluit, en dieselfde manier van folter en mishandeling wat hulle op diere toepas, sal hulle aan kinders doen.")

Love is not tolerated. Disobedience is not tolerated. Physical pain is endured where scars appear on their bodies, or they experience internal pain which can not be medically explained.

Gardiner (1991:11) writes a gruesome story of a sixteen-year-old girl. She tells: "' $n$ Jaar later het hulle my gedwing om 'n aborsie te hê. Ek was ses maande swanger. Dit was seer. Toe het hulle my en my dooie baba na 'n heksevergadering geneem ... Toe het hulle my gedwing om my baba te eet." ("A year later they forced me to have an abortion. I was six months pregnant. It hurt. They then took my dead baby to a witches meeting ... They then forced me to eat my baby.")

\section{Weirdness / strange languages spoken / crime and rituals}

The adolescent is forced to participate in crime through rituals "... and to participate in like cannibalism ... uhm ... sex with the dead uh ... that kind of stuff you will find, bestiality, that's pretty much forced." (... en om deel te neem aan kanibalisme ... hm ... seks met dooies hm .. hierdie tipe dinge, iy sal vind, dierlikheid, dit word op jou afgedwing.")

\section{DATA-CONTROL AND -RESULTS}

The interviews were extremely long and the respondents used many words. Both the researcher and independent coder questioned the meaning thereof. Possible meanings could be that the respondents recovered their voice, or that they merely used a lot of words to distance themselves from the researcher. The themes of the respondents' lifeworlds are summarized in table 3 .

\section{Realities and confusion}

The adolescents previously involved in Satanism have a different reality to those not previously involved in Satanism. Both adolescents spoke of confusion a couple of times, and that they don $=t$ know which rules apply. One respondent verbalized her reality as follows: "Reality. What is reality? Normality? What is normality? The reality, my reality was a life filled with sight and experiences of a spiritual dimension." ("Realiteit, wat is realiteit? Normaliteit? Wat is normaliteit? Vir my was my realiteit ' $n$ lewe gevul met from human sacrifices to animal sacrifices and disciplining the adolescents in the most gruesome ways.

\section{Table 3 : The life-world of adolescents previously involved in Satanism}

\begin{tabular}{ll|} 
- & Realities and confusion \\
- & Brutality/pain/trauma/gruesomeness \\
- & rituals \\
- & Power and control though fear, with loss of choice \\
- & Never safe/never rid of persecution \\
- & Denied access to mother-love/suppression of emotion/ \\
- & Death and suicide (deathwish) \\
- & Emolation (separateness) \\
- & Feelings of guilt \\
- & Disillusionment \\
\hline
\end{tabular}


They expand on the weirdness and strange languages spoken: “... en ek het geweldige krag ook gehad. Ek kon dinge aan die brand steek met my oë, ek kon tafels beweeg, stoele beweeg ..."

("... and I had tremendous power. I could set things alight with my eyes, I could move tables, move chairs.") The adolescent has the power to make contact with demons, and demons with him, and the demons manifest in physical form: "Ek het persoonlike kontak met hulle gehad. Ek kon hulle sien, hulle het in 'n fisiese vorm voor my gemanifesteer." ("I had personal contact with them. I could see them, they would manifest in physical form, right in front of my eyes.")

Superintendent Rabalt went into more detail into Satanism and crime, which included rituals: "Ja, satanisme is self nie ' $n$ misdaad nie, maar wat gebeur is ' $n$ misdaad." ("Yes, Satanism is no crime, but what happens is criminal.")

"Soos om graffiti op mure te spuit, ... is opsetlike saakbeskadiging, ... om ... bloed uit 'n kat, 'n lewendige kat, uit te haal ... is dieremishandeling, om die diere, of die kat se pote af te sny, selfs terwyl die kat, hond, ... hoenders of wat ookal nog lewe, dis dieremishandeling. Aborsie word gepleeg, deur ' $n$ fetus te laat afkom en dit te offer..."

("Like painting graffiti on walls, ... it is malicious intent, ... to ... take blood from a cat, a live cat ... is cruelty to animals, to cut of the animal's, or the cat's paws, even while the cat, dog ... chicken or whatever is still alive, that is cruelty to animals. Abortion is committed, aborting the fetus and offering it ...")

Lourens, a pastoral consultant, had more to say about strange languages:

“... en nou dien hulle Satan, en ewe skielik word al hierdie krag aan hulle gegee, om byvoorbeeld ' $n$ tafel op te lig, en jy staan aan die een kant van die kamer en aan die ander kant tel jy die tafel op ..."

(“... and they now serve Satan, and suddenly, they have all this power, for example to lift a table, and you stand on one side of the room, and on the other side you lift the table...")

\section{Power and control through fear, with loss of choice}

The adolescent's right of choice is taken from him the moment he opts for Satanism: "... daar was geweldige manipulasie en beheer van vrees. Ek kan net sê dat ek nie kan dink dat daar ooit 'n tyd was by enige kultus-byeenkoms of ritueel dat daar nie vrees, intimidasie, pyn of mishandeling plaasgevind het nie." ("... there were tremendous manipulation and control of fear. All I can say is that I don't think there were ever a time during any cult-meeting or -ritual that there were no fear, intimidation, hurt or abuse.")

Superintendent Kobus Jonker (1996) observed that fear plays an important role in Satanism, as well as in the removal of choices from the adolescent: "Daar ... vrees speel 'n baie groot rol, want hulle wil by elkeen ' $n$ vreeskonsep daarplaas dat jy nie kan wegbreek uit die beweging nie." ("There ... fear plays an important role, because they want to create a fear-concept in all members, so that they can't break away from the movement.")

\section{Paranoia / distrust / secrecy}

Paranoia is created and strengthened in the Satanic movement. Nobody is allowed to trust anybody, and no friends are allowed.

The demonic voices contribute to the adolescent's paranoia: "They'll (demons), tell you like, I mean ... stupid things even, even if you sit down in a crowd full of people, they'll say "ja ... look at those people looking at you, they know, they know what you are, they know you're scum..." ("Hulle (demone) sê byvoorbeeld vir jou, ek bedoel ... simpel goed selfs, selfs as $j y$ tussen 'n groep mense sit, sal hulle sê "ja ... kyk hoe kyk die mense vir jou, hulle weet, hulle weet wat jy is, hulle weet jy is die skuim van die aarde...")

Demonic voices differ from voices in psychosis. The demonic voices keep them company, give advice and tell them things about other people.

Malan (1992:15) notices: "Onder die Sataniste heers daar presies die teenoorgestelde gesindheid as onder Christene. Daar is geen liefde en onderlinge diensbetoning waarin die een die ander hoër ag as homself nie, maar gedurige agterdog, wedywering, intimidasie en gedwonge diens aan Satan. Lede vernietig mekaar letterlik om bo uit te kom." ("In Satanism exactly the opposite applies than to Christianity. There is no love and mutual subservience where one considers the other higher than himself, but continuous suspicion, competition, intimidation and forced senice to Satan. Members destroy each other literally in order to reach the top.")

With initiation into Satanism, a strict code of secrecy is forced upon the adolescent. The context paranoia and confidentiality lies in the characteristics of demons and Satanists. Robbie's (1996) experience of demons is: "want $j y$ kan 'n bose gees - hoe sê ek, jy kan hom ruik, jy kan hom sien, jy kan hom hoor. So hy KAN jou afluister, nê." ("... because a demon - how can I put it, you can smell him, you can see him, you can hear him. So he CAN eavesdrop, not so?")

\section{Never safe / never rld of persecution}

Once an adolescent becomes involved in Satanism, he is never again safe from persecution from other cult-members and Satan. He continuously looks over his shoulders. One adolescent experienced this: "I could never leave the house on my own, they would, if I left the house, there was a ninety nine percent chance l'd be raped or beaten or something, as soon as I get out of the house." ("Ek kon nooit die huis alleen verlaat nie, hulle sal, indien ek die huis sou verlaat was daar 'n nege-en-negentig persent kans dat ek verkrag, geslaan of dat iets sou gebeur sodra ek uit die huis uit gaan.")

Although this aspect was considered very important to both adolescents and their parents, the books, literature and experts with whom control-discussions were conducted, did not consider it significant.

Superintendent Jonker casually mentioned it: “... as ... die sataniste ... as $j y$ weggebreek het ... hulle gaan jou mos nie los nie. Hulle gaan mos nou weer kom." ("... if ... the Satanists ... if you break away from them ... they won't leave you. They will come again.")

\section{Denled access to mother-love / suppression of emotion I defense mechanisms}

Emotions are suppressed. The adolescent can't remain standing if he experiences emotions or love. The trauma he experiences is too vast. He starts dissociating and develops multiple personalities. In Satanism multiple personalities are developed for self-gain, like developing secrecy: "... and I had to get the puzzle pieces together, so that I could get a picture of what I knew was actually going on and, at that stage, uhm, I wasn't even aware that there were alters, or personalities, or dissociate identities, or whatever you call them." ("... en ek moes die legkaart saamflans, sodat ek ' $n$ geheelbeeld kon kry van wat eintlik aangaan, op daardie stadium, hm, was ek nie eens bewus van alters, of persoonlikhede, of dissosiatiewe identiteite, of wat jy dit ookal wil noem nie.")

In her practice Nicolene (1996) encountered this problem of not being able to show emotions: "... en baie van hulle het ' $n$ probleem met liefde ... en verstaan nie 
as 'n mens sê God het hulle lief nie ... en dan het hulle in baie harder benadering rondom dit ..." ("... and many of them have a problem with love ... they can't comprehend God's love ... and they have a much fiercer approach in this regard ...") and “... dan ... dissosieer iy die emosionele kant in 'n groot mate ... dat hulle nie die vrees voel nie, dat hulle nie die weersin voel nie, en ... en iy word eintlik iemand anders, iy word eintlik iemand sonder emosie ..." ("... then ... you dissociate the emotional side to a great extend ... in order for them not to feel the fear, not to feel the aversion, and ... you actually become somebody e/se, you become someone without emotion...")

\section{Death and suicide (deathwish)}

Death and deathwishes are intrinsically associated with Satanism. During the rituals the adolescent comes into contact with the cruelest form of death imaginable.

The adolescents often apply suicide attempts or actually commit suicide. They can even die during rituals.

They have a longing to die: "/ used to feel things, like I wanted to die, but I couldn't say why ... I wanted to die. And I used to pray, and I would say, Lord please kill me. I don't want to live, but I could never say why I wanted to die." ("Ek het dinge gevoel, soos dat ek wou doodgaan, maar ek kon nie sê waarom nie. En ek het gebid, dan sou ek sê, God, maak my dood, asseblief. Ek will nie leef nie, maar ek kon nooit verklaar waarom ek wou doodgaan nie.")

Lourens (1996) discuss death and suicide in the adolescent with great piety: "Hulle verloor alle lus en alle dryt om aan te gaan, en self iets te maak van hulle lewe. Meeste van hulle eindig in selfmoord." ("They loose all desire and drive to carry on, to make something of their lives. Most of them commit suicide.")

\section{Isolation (separateness)}

The adolescent experiences the other reality of Satanism as isolation and separateness from others. Through this isolation Satanists strengthen their powerbase amongst adolescents. One respondent described her isolation: "I am different. I have always been separate. Separate from others." ("Ek is anders. Ek was nog altyd alleen. Verwyder van ander.")

Nicolene (1996) states in this regard: “... hulle voel ook anders as ander mense, hulle voel soos ' $n$... soos ' $n$ ander spesie." (AY they feel different from other people, they feel like another ... like another species.")

\section{Emotional exhaustion}

Emotional exhaustion and passivity go hand in hand. Both respondents and their mothers recognized this and commented on it: "I, I couldn't even stay awake for more than a few hours at a time..." ("Ek, ek kon nie vir langer as "n paar uur op "n slag wakker bly nie ...")

Brown (1991:153) experienced the emotional exhaustion: "Jy sal gou die simptome van uitputting, pyn, depressie en ander kwale in jou fisiese liggaam herken as aanduidings dat jou geestelike liggaam in'n verbete stryd betrokke is." "You will quickly recognize the symptoms of exhaustion, pain, depression and other symptoms in your physical body as indication that your spiritual body is involved in an obstinate battle.")

\section{Feelings of guilt}

Especially the parents experience tremendous feelings of guilt regarding their children's involvement in Satanism: "I struggled a great deal with those guiltfeelings ... " ("Ek het baie gesukkel met skuldgevoelens ...") and "That (guilt-feelings), I got all the time because I was a bad mother, and it's my fault ..." ("Daardie (skuldgevoelens), ek het dit die hele tyd gehad omdat ek ' $n$ slegte ma was, dit is my fout ...")

Feelings of guilt are seldom mentioned in the literature. Nicolene mentioned it. Friesen (1992:90) shows that the adolescent as well as the parent often experience feelings of guilt: "She (mother) had become depressed after finding out what had happened to her daughter that she was highly suicidal for a long time." ("Sy (moeder) het depressief geword nadat sy uitgevind het wat met haar dogter gebeur het, sy was vir 'n lang tyd geneig tot selfmoord.")

\section{Disillusionment}

Both parents verbalized an absolute nonplussed disillusionment when they realized their children's involvement: “... I had no concept of what was going on. It was only afterwards when she went for therapy, that I found out that it happened Y it was a big shock for me ..." ("... ek het geen idee gehad van wat aangaan nie. Dit was slegs daarna, nadat sy terapie ontvang het, dat ek uitgevind het wat gebeur het ... dit was vir my ' $n$ groot skok ...")

In data-control there is little reference to disillusionment. It was only Nicolene (1996) who discussed it during the control-discussion: “Dis vir hulle die meeste van die tyd ' $n$ baie groot skok. Hulle weet niks van Satanisme af nie, hulle het nooit gedink hulle kind is betrokke in so-iets nie." ("Most of the time is comes as a big shock. They know nothing about Satanism, and never thought their child will get involved in something like that.")

\section{Rock music}

This aspect received no attention whatsoever during discussions with adolescents. It did however, appear in the datacontrol in many instances. It did not only appear repeatedly during control-discussions but also in various books exclusively related to Satanism and rock music.

Elaine in Brown's $(1991: 122,123)$ book tells how rock stars agreed to serve Satan, in exchange for money and fame. She further tells how she, as a high priestess, went to recording studios and placed demonic curses on each record and tape.

She sometimes even called on demons that would then speak on the records, the so-called messages that can be heard, when the records are played back.

"Baie van die liriek is in werklikheid 'n beswering wat demone oproep wanneer die liedjies gesing word. Die doel daanan is tweërlei: eerstens om beheer uit te oefen oor die luisteraar, en tweedens om die luisteraar met werklike beswerings te voorsien wat hy / sy kan gebruik om demone op ander oor te plaas." ("Many of the lyrics are in reality curses calling on demons when they are sang. The purpose is twofold: firstly to control the listener, and secondly to provide the listener with actual curses he or she can use to place demonic curses on other people.")

\section{GUIDELINES FOR NURSE PRACTITIONERS:}

- An irrefutable belief in Jesus Christ as personal Redeemer and Savior;

- $\quad$ Gather knowledge regarding Satanism, before attempting to help the adolescent;

- Accept the adolescent unconditionally;

- Work in a team of reborn Christians, inclusive of a lawyer, medical practitioner, spiritual advisor, church, psychiatrist, pscychiatric nurse and police;

- Create a strong personal support system;

- $\quad$ Provide the adolescent with the 
opportunity to continuously discuss the situation, without being judgmental;

- Teach them how to get in touch with their emotions again;

- Do not let them choose between realities;

- Show Christian love towards the adolescent;

- Persist with assistance until the adolescent is strong enough to continue on his own;

- Don't get despondent if the adolescent has set-backs during treatment; - Involve the parents in this process.

\section{SHORTCOMINGS, CONCLUSIONS} AND RECOMMENDATIONS

One of the shortcomings was that one respondent no longer was an adolescent, although she was involved in Satanism during her adolescent years, and her level of involvement was higher than the average adolescent involved in Satanism, since she had a higher order of rank (she was a high priestess in a coven).

Both respondents were female. Other information could possibly have been obtained if a boy was involved in the research. The respondents had no friends. The tape recorder had an inhibiting effect on respondents. Data that could possibly have been obtained, might be lost.

Another factor could be that the researcher went into the research from a "don't know" position. The researcher supposes that different data could have been obtained, depending on the interviewer. The basic data obtained would probably remain the same.

The caregiving profession must take notice of the existence of different realities. The reality leads to confusion for everybody involved in assisting adolescents involved in Satanism.

Voices are not necessarily schizophrenic voices. It could be voices from another reality.

The recommendation is that a caregiving model is designed and implemented to concretely assist these adolescents.

The caregiving model must be introduced widespread and should not only be available to an exclusive group. Further research should be undertaken to introduce the field more extensively and to prove transferability.

\section{SUMMARY}

Everything's is not always how it seems. The responsibility is that of the nursing professional and other caregiving professions to investigate all possibilities and adjust caregiving to fit the need of those being helped.

\section{BIBLIOGRAPHY}

BOTES A. 1989. ' $n$ Model vir wetenskapsbeoefening in die verpleegkunde. Johannesburg: Randse Afrikaanse Universiteit. (D.Cur-thesis).

BROWN R. 1991. Hy het gekom om die gevangenis te bevry. Westdene: Evangelie Uitgewers.

CITIZEN. 1992. Johannesburg, 23 September.

CRESWELL J.W. 1994. Research design, qualitative and quantitative approaches. Thousand Oaks, California: Sage.

DIE HUISGENOOT. 1995. Johannesburg, 10 Augustus.

FRIESEN J.G. 1992. Uncovering the mystery of MPD. San Bernadino, ca, USA: Here's Life Publishers, Inc.

GARDINER J., \& H. 1990. Satanisme, Suid-Afrika se jeug in versoeking. Kaapstad: Blackshaws (Edms) Bpk.

KVALE S. 1983. The qualitative research interview: A phenomenological and hermeunitical mode of understanding. Journal of Phenomenological Pscyhology, 14:171-196.

LINCOLN Y.S., \& GUBA E.G. 1985. Naturalistic inquiry. Beverly Hills: Sage

MALAN J.S. 1992. Verleidende geeste. Silverton: Promedia Drukkers.

ORAL ROBERTS UNIVERSITY: ANNA VAUGHN SCHOOL OF NURSING. 1990. Self-study report, submitted to the Council of Baccalaureate and Higher Degree Program, National League of Nursing, August 1990. Volume I - Narrative by Criteria. Tulsa, Oklahoma: Oral Roberts University: Anna Vaughn School of Nursing: 136 B 142.

WOODS N.F. \& CATANZARO M. 1988. Nursing research: Theory and practice. St. Louis Mosby.

\section{DISCUSSIONS HELD WITH EXPERTS}

SUPERINTENDENT KOBUS JONKER, associated to the occult branch on national level, based in Pretoria (1996)

SUPERINTENDENT ROBBIE RABBALT, associated to the occult branch in the Vaal Triangle-area (1996).

Interviews were also conducted with a clinical psychiatrist, Nicolene, and a pastoral consultant, Lourens, who requested that confidentiality be maintained. 